\title{
МОРФОМЕТРИЧНІ АСПЕКТИ АНАЛІЗУ ВІКОВИХ СТРУКТУРНИХ ЗМІН
} АРТЕРІЙ СЕЧІВНИКА

Морфометричні аспекти аналізу вікових

М. С. Гнатюк, С. О. Нестерук, Л. В. Татарчук, Н. Я. Монастирська

Тернопільський національний медичний університет імені І. Я. Горбачевського МОЗ України

Резюме. Дослідження ангіоархітектоніки інтраорганного судинного русла в нормі й при різних патологічних станах постійно знаходиться в полі інтересів науковців. Варто зазначити, що різнотиповість вікових судинних реакцій сечівника залишаються суперечливими.

Мета дослідження - морфометрично дослідити вікові структурні зміни артерій сечівника.

Матеріали і методи. Комплексом морфологічних методів досліджені артерії сечівника 15 свиней-самців в'єтнамської породи, яких поділили на 2 групи: перша нарахувала 8 інтактних практично здорових тварин віком 3,5-4 місяці, друга - 7 інтактних свиней віком 6,5-7 місяців. Із сечівника виготовляли гістологічні мікропрепарати. Проводили морфометрію артерій сечівника і вимірювали їх зовнішній та внутрішній діаметри, товщини медії та адвентиції, висоту ендотеліоцитів, діаметр їх ядер, визначали індекс Вогенворта, ядерно-цитоплазматичні відношення в ендотеліоцитах та відносний об'єм ушкоджених ендотеліоцитів. Кількісні показники оброблялися статистично.

Результати. Встановлено, що з віком суттєво змінювалися моророметричні параметри артерій переважно дрібного калібру сечівника. Зовнішній діаметр досліджуваних судин збільшився усього на 0,6 \%, товщина медії - на 9,8 \%, індекс Вогенворта - на 21,9\%, товщина адвентиції - на 35,2 \% (p<0,001). Внутрішній діаметр артерій дрібного калібру зменшився на 9,3 \% $(p<0,001)$. Виявлене свідчило про вікове зниження пропускної здатності артерій сечівника і погіршання його кровопостачання. 3 віком виникають атрофрічні та апоптичні зміни в ендотеліоцитах при стабільності клітинного структурного гомеостазу.

Висновки. Вікова структурна перебудова артерій сечівника у дослідних тварин характеризується потовщенням їх стінки, зростанням товщини медії, адвентиції, індексу Вогенворта, звуженням їх просвіту, зниженням пропускної спроможності досліджуваних судин та погіршанням кровопостачання органа. 3 віком зменшується висота ендотеліоцитів, діаметри їх ядер, зростає відносний об'єм ушкоджених ендотеліоцитів при
Morphometric aspects of the analysis of age-related structural changes of the urethral arteries

M. S. Hnatjuk, S. O. Nesteruk, L. V. Tatarchuk, N. Ja. Monastyrska

I. Horbachevsky Ternopil National Medical University e-mail: hnatjuk@tdmu.edu.ua

Summary. The study of angioarchitectonics of the intraorganic vascular bed in the organs at normal and in various pathological conditions is constantly in the field of interest of scientists. The variety of age-related vascular reactions of the urethra remain contradictory.

The aim of the study - morphometric research of age-related structural changes in the urethral arteries.

Material and Methods. The arteries of the urethra of 15 male Vietnamsese pigs, which were divided into 2 groups, were morphologically studied. Group 1 counted 8 intact practically healthy animals aged 3.5-4 months, group $2-7$ intact pigs aged 6.5-7 months. Histological micronutrients were made from the urethra. Morphometry of urethral arteries was performed and their outer and inner diameters, media and adventitial thicknesses, endotheliocyte height, nucleus diameter, Wagenworth index, nuclear cytoplasmic ratio in endotheliocytes and relative volume of damaged endotheliocytes were measured. Quantitative indicators were processed statistically.

Results. The morphometric parameters of arteries of small caliber of the urethra changed significantly with age. The outer diameter of the studied vessels increased by $0.6 \%$, the thickness of the media - by $9.8 \%$, the Wagenworth index - by $21.9 \%$, the thickness of the adventitia - by $35.2 \%(p<0.001)$. The inner diameter of small caliber arteries decreased by $9.3 \%(p<0.001)$. The detected indicated an age-related decrease of capacity of the urethral arteries and deterioration of its blood supply. With age, atrophic and apoptotic changes in endothelial cells occur at stability of cellular structural homeostasis.

Conclusions. Age-related structural rearrangement of ureteral arteries in experimental animals is characterized by thickening of their wall, increasing media thickness, adventitia, Wagenworth index, narrowing of their lumen, reduced capacity of the studied vessels and deterioration of blood supply of organ. With age, the height of endotheliocytes decreases, the diameters of their nuclei increase, and the relative volume of damaged endotheliocytes increases with the stability of cellular 
стабільності клітинного структурного гомеостазу. Ступінь вікового ремоделювання досліджуваних судин домінує в артеріях дрібного калібру сечівника.

Ключові слова: сечівник; артерії; морфометрія.

\section{ВСТУП}

Вивчення ангіоархітектоніки інтраорганного судинного русла в нормі й при різних патологічних станах, де локалізовані складні процеси взаємовідношень крові та тканин, постійно знаходиться в полі інтересів клініцистів і морфологів [1, 2]. Дослідження вікових структурних змін артерій та вен різних органів $є$ актуальною проблемою сучасної медичної науки [3]. При цьому варто зазначити, що вікові структурно-срункціональні зміни артеріального русла сечівника вивчені недостатньо, а різнотипність вікових судинних реакцій різних органів продовжують залишатися суперечливими. Разом 3 тим відомо, що артеріальне русло та його зміни відіграють важливу роль у морфогенезі уражень сечівника [4].

Метою дослідження було морфометрично вивчити вікові структурні зміни артерій сечівника.

\section{МАТЕРІАЛИ I МЕТОДИ}

Комплексом морфологічних методів досліджені артерії сечівника 15 свиней-самців в'єтнамської породи, яких поділили на 2 групи: перша нарахувала 8 інтактних практично здорових тварин віком 3,5-4 місяці, друга - 7 інтактних свиней віком 6,5-7 місяців. Евтаназію свиней здійснювали кровопусканням в умовах тіопентал-натрієвого наркозу. Вирізані шматочки із сечівника фріксували в $10 \%$ нейтральному розчині фрормаліну і після відповідного проведення через етилові спирти зростаючої концентрації заливали у парафрінові блоки за загальноприйнятою методикою. Гістологічні зрізи товщиною 5-7 мкм після депарафрінізації фрарбували гематоксиліном та еозином, за ван-Гізон, Маллорі, Вейгертом, Массоном, толуїдиновим синім [5]. Проводили морфометрію артерій середнього (зовнішній діаметр 51125 мкм) та дрібного (зовнішній діаметр 26-50 мкм) калібрів сечівника $[2,6]$. При морфометрії артерій вимірювали їх зовнішній (ЗД) та внутрішній (ДВ) діаметри, товщини медії (ТМ) та адвентиції (ТА), висоту ендотеліоцитів (ВЕ), діаметр їх ядер (ДЯЕ), визначали індекс Вогенворта (IB), ядерно-цитоплазматичні відношення в ендотеліоцитах (ЯЦВ) та відносний об'єм ушкоджених ендотеліоцитів (ВОУЕ) $[1,7,8]$. Морфометрію вказаних судин проводили за допомогою світлового мікроскопа «Olimpus BX-22» 3 цифровою відеокамерою та пакетом прикладних програм «Відео Тест 5,0» та «Відео Розмір 5,0». Кількісні величини оброблялися статистично. Об- structural homeostasis. The degree of age-related remodeling of the studied vessels dominates in the arteries of small urethral caliber.

Key words: urethra; arteries; morphometry.

робку результатів виконано у відділі системних статистичних досліджень Тернопільського національного медичного університету імені І. Я. Горбачевського МОЗ України в програмному пакеті Statsoft STATISTIKA. Різницю між порівнювальними величинами визначали за критеріями Манна - Уїтні та Стьюдента [9].

Усі маніпуляції та евтаназію свиней проводили із дотриманням основних принципів роботи з експериментальними тваринами відповідно до положення Європейської конвенції про захист хребетних тварин, які використовуються для експериментальних та інших наукових цілей (Страсбург, 1986), Загальних етичних принципів експериментів на тваринах, ухвалених Першим національним конгресом 3 біоетики (Київ, 2001), а також Закону України «Про захист тварин від жорстокого поводження» (від 21.02.2006) [10].

\section{РЕЗУЛЬТАТИ Й ОБГОВОРЕННЯ}

Отримані морфометричні параметри досліджуваних артерій сечівника показані в таблицях 1, 2. Результати усестороннього аналізу представлених кількісних морфологічних показників показали, що зовнішній діаметр артерій середнього калібру з віком збільшився всього на 0,2 \%, товщина медії - на 3,9 \%, адвентиції - на 12,4 \%, індекс Вогенворта - на 8,1 \% ( $<<0,001)$, внутрішній діаметр (просвіт) зменшився на 4,1\%. Висота ендотеліоцитів досліджуваних судин при цьому зменшилася на 3,5 \%, діаметр їх ядер - на 3,2 \%, відносний об'єм ушкоджених ендотеліоцитів зріс у 1,2 раза, ядерно-цитоплазматичні відношення зберігали стабільність.

Встановлено, що з віком морфометричні параметри артерій дрібного калібру сечівника змінювалися більш виражено порівняно з артеріями середнього калібру. Варто вказати, що в умовах даного експерименту зовнішній діаметр досліджуваних судин збільшився всього на 0,6 \%. Внутрішній діаметр артерій дрібного калібру з віком із вираженою статистично достовірною різницею $(p<0,001)$ зменшився на 9,3 \%. Товщина медії досліджуваних судин в експериментальних тварин молодшої вікової групи дорівнювала $(6,30 \pm 0,04)$ мкм, а у свиней старшої вікової групи - $(6,92 \pm 0,05)$ мкм. Між наведеними морфометричними параметрами виявлена статистично достовірна різниця $(p<0,001)$ і останній морфометричний параметр перевищував попередній на 9,8\%.
Вісник медичних і біологічних досліджень Bulletin of Medical and Biological Research
3(9),2021 


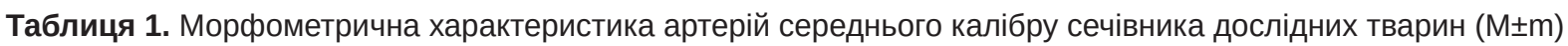

\begin{tabular}{|c|c|c|}
\hline \multirow{2}{*}{ Показник } & \multicolumn{2}{|c|}{ Група спостереження } \\
\hline & перша & друга \\
\hline ЗД, мкм & $83,70 \pm 0,42$ & $83,86 \pm 0,39$ \\
\hline ВД, мкм & $54,10 \pm 0,30$ & $51,88 \pm 0,27^{\star \star *}$ \\
\hline TM, мКM & $15,30 \pm 0,04$ & $15,90 \pm 0,06^{\star \star *}$ \\
\hline TA, мкм & $14,30 \pm 0,03$ & $16,08 \pm 0,06^{\star * *}$ \\
\hline $\mathrm{IB}, \%$ & $239,4 \pm 3,1$ & $261,3 \pm 3,3^{* \star *}$ \\
\hline BE, мкM & $6,20 \pm 0,06$ & $5,98 \pm 0,03^{\star \star}$ \\
\hline ДЯЕ, мкм & $3,10 \pm 0,03$ & $3,00 \pm 0,02^{\star \star}$ \\
\hline ЯЦВ & $0,252 \pm 0,002$ & $0,254 \pm 0,003$ \\
\hline ВОПЕ, \% & $2,30 \pm 0,03$ & $2,80 \pm 0,03^{\star \star \star}$ \\
\hline
\end{tabular}

Примітка. ** - p<0,01; *** - p<0,001 порівняно з першою групою спостережень.

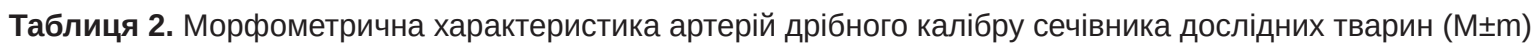

\begin{tabular}{l|c|c}
\hline \multirow{2}{*}{ Показник } & \multicolumn{2}{|c}{ Група спостереження } \\
\cline { 2 - 3 } & перша & друга \\
\hline ЗД, мкм & $33,70 \pm 0,24$ & $33,90 \pm 0,21$ \\
\hline ВД, мкм & $17,10 \pm 0,12$ & $6,50 \pm 0,12^{\star \star \star}$ \\
\hline ТМ, мкм & $6,30 \pm 0,04$ & $5,68 \pm 0,05^{\star \star *}$ \\
\hline ТА, мкм & $4,20 \pm 0,03$ & $473,6 \pm 4,8^{\star \star *}$ \\
\hline ІВ, \% & $388,4 \pm 3,3$ & $5,80 \pm 0,04^{\star *}$ \\
\hline ВЕ, мкм & $6,10 \pm 0,06$ & $2,96 \pm 0,02^{\star *}$ \\
\hline ДЯЕ, мкм & $3,10 \pm 0,03$ & $0,260 \pm 0,004$ \\
\hline ЯЦВ & $0,256 \pm 0,002$ & $2,80 \pm 0,03^{\star \star *}$ \\
\hline ВОПЕ, \% & $2,40 \pm 0,03$ &
\end{tabular}

Примітка. ${ }^{* *}-p<0,01 ;{ }^{* \star}-p<0,001$ порівняно 3 першою групою спостережень.

Майже аналогічно змінювалася також товщина медії досліджуваних судин сечівника. Так, у першій групі спостережень вказаний моророметричний параметр дорівнював $(4,20 \pm 0,03)$ мкм, а у другій групі тварин - $(5,68 \pm 0,04)$ мкм. Дані цифрові величини 3 високою статистично достовірною різницею ( $<<0,001)$ відрізнялися між собою. При цьому останній морфометричний параметр артерій дрібного калібру сечівника перевищував попередній на 35,2%. У досліджуваних експериментальних умовах індекс Вогенворта артерій дрібного калібру сечівника з високим ступенем статистичної достовірності ( $p<0,001)$ збільшився на 21,9 \%. Вікове потовщення стінки досліджуваних судин, збільшення товщини медії, адвентиції, виражене зростання індексу Вогенворта і зменшення їх просвіту свідчили, що з віком виражено знижується пропускна здатність артерій дрібного калібру сечівника [2]. Виявлені зміни досліджуваних моророметричних параметрів артерій свідчать про погіршання кровопостачання органів.

Висота ендотеліоцитів артерій дрібного калібру сечівника дослідних тварин молодшої вікової групи дорівнювала $(6,10 \pm 0,05)$ мкм, а $з$ віком даний морфометричний параметр статистично достовір- но $(p<0,01)$ зменшився до $(5,80 \pm 0,04)$ мкм, тобто на 4,9\%. Виявлене зменшення досліджуваних клітин свідчить про наявність вікових атрофічних змін. У даних умовах експерименту зі статистично достовірною різницею $(p<0,01)$ знизилися також моророметричні параметри ядер ендотеліоцитів на 4,5 \%. Ядерно-цитоплазматичні відношення у ендотеліоцитах досліджуваних судин першої групи тварин дорівнювали 0,256 00,002, а у другій групі спостережень - 0,260 0,004 , тобто з віком вони майже не змінювалися. Встановлене вказує, що така постійність ядерно-цитоплазматичних відношень у ендотеліоцитах артерій дрібного калібру сечівника не змінюються, що підтверджує стабільність вікового структурного клітинного гомеостазу $[1,7,11]$.

Відносний об'єм ушкоджених ендотеліоцитів артерій дрібного калібру сечівника у першій групі

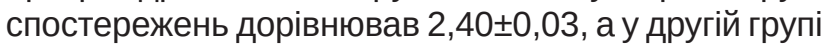
тварин - $(2,80 \pm 0,003) \%$. Наведені морфометричні параметри між собою статистично достовірно відрізнялися $(p<0,001)$ і останній параметр перевищував попередній на 16,6 \%. Збільшення кількості ушкоджених клітин при цьому деякі дослідники пояснюють віковим зростанням апоптично змінених клітин [12]. 
Відомо, що ендотеліоцити судин синтезують різні біологічно активні речовини, необхідні для регуляції життєво важливих функцій організму: зсідання крові, регуляція тонусу судин, скоротливість серця, диорузія води, іонів, продуктів метаболізму. Ендотеліоцити здійснюють бар'єрну, продукційну, гемостатичну, метаболічну, транспортну, репаративну фрункції, синтезують оксид азоту (NO). Ушкодження значної кількості ендотеліоцитів може призводити до їхньої дисфункції, блокади NOсинтази, зменшення синтезу NO, активації процесів його деградації, спазму та звуження судин [2, 13]. Останнє погіршує кровопостачання органів, призводить, підтримує та посилює гіпоксію, яка ускладнюється набряком, дистрофрією, некробіозом тканин і клітин. Варто вказати, що світлооптично патогістологічних змін у артеріях неушкодженого сечівника експериментальних тварин старшої вікової групи не виявлено. Вираженішу вікову структурну перебудову артерій дрібного калібру неушкодже-

\section{СПИСОК ЛІТЕРАТУРИ}

1. Гнатюк М. С. Особливості структурної перебудови артерій язика при десквамативному глоситі / М. С. Гнатюк, І. В. Боднарчук, Л.В.Татарчук // Вісник наукових досліджень. - 2019. - № 2. - C. 85-89. DOI: 10.11603/24158798.2019.2.10022.

2. Макаров М. А. Роль дисфункции эндотелия и регидности артерий в патогенезе хронической обструктивной болезни легких / М. А. Макаров, С. Н. Авдеев, А. Г. Чучалин // Терапевтический архив. - 2012. - № 3. - C. 74-80.

3. Age-related features of tongue remodeling in the experimental animals / M. S. Hnatjuk, I. V. Bodnarchuk, L. V. Tatarchuk, P. A. Hasiuk // Biomedical and Biosocial Anthropology. - 2018. - No. 33. P. 36-40. DOI: 10.31393/ bba33-2018-06.

4. Kashinath Nayak A. A clinicoetiological study of uretritis in man attending sexually transmitted disease clinic at a tertiary hospital / A. Kashinath Nayak, T. Anoop, S. Sacohidanand // Indian Journal of Sexually Transmitted Disease and AIDS. - 2017. Vol. 38 (2). P. 136-141. DOI: 10.4103/ijstd.IJSTD_98_15.

5. Горальський Л. П. Основи гістологічної техніки і морфофункціональні методи досліджень у нормі та при патології / Л. П. Горальський, В. Т. Хомич, О. І. Кононський. - Житомир : Полісся, 2011. - 288 с.

6. Шорманов С. В. Гистологические и ультраструктурные изменения печени при экспериментальном стенозе легочного ствола на стадии декомпенсации / С. В. Шорманов, С. В. Куликов // Морфология. - 2010. № 3. - C. 46-50. ного сечівника пояснюють тим, що вказані судини в органах відіграють основну функцію у регуляції кровотоку, тобто вони знаходяться у більшому напруженні, порівняно з більшими артеріями, і вони першими та більше реагують у різних фрізіологічних та патологічних умовах.

\section{вИСновки}

Вікова структурна перебудова артерій сечівника у дослідних тварин характеризується потовщенням їх стінки, зростанням товщини медії, адвентиції, індексу Вогенворта, звуженням їх просвіту, зниженням пропускної спроможності досліджуваних судин та погіршанням кровопостачання органа. 3 віком зменшується висота ендотеліоцитів, діаметри їх ядер, зростає відносний об'єм ушкоджених ендотеліоцитів при збереженій стабільності клітинного структурного гомеостазу. Ступінь вікового ремоделювання досліджуваних судин домінує в артеріях дрібного калібру сечівника.

7. Автандилов Г. Г. Основы количественной патологической анатомии / Г. Г. Автандилов. - М. : Медицина, 2002. - 240 c.

8. Wogenvoort C. A. Smooth muscle content of pulmonary arterial media in pulmonary venous hypertension compared with forms of pulmonary hypertension / C. A. Wogenvoort, N. Wogenvoort // Pulmonary Venous Hypertension. - 1982. - Vol. 81 (5). - P. 681-585. DOI: 10.1378/chest.81.5.581.

9. Гржибовский А. И. Сравнение количественных данных двух парных выборок с использованием программного обеспечения Statistica и SPSS: параметрические и непараметрические критерии / А. И. Гржибовский, О. В. Иванов, М. А. Горбатова // Наука и здравоохранение. - 2016. - № 3 - C. 5-25. DOI: 10.34689/ SH.2016.18.3.001.

10. Резніков О. Г. Загальні етичні принципи експериментів на тваринах / О. Г. Резніков // Ендокринологія. 2003. - № 8. - С. 142-145.

11. Саркисов Д. С. Структурные основы адаптации и компенсации нарушенных фрунцций / Д. С. Саркисов. М. : Медицина, 1998. - 230 с.

12. Ащеулова Т. В. Апоптоз: сигнальні шляхи та значення при кардіометаболічній патології / Т. В. Ашеулова. - Харків : Харківський національний медуніверситет, 2016. - 114 c.

13. Загородній М. І. Ендотеліальна дисфункція при артеріальній гіпертензії: сучасні погляди на причини і механізми розвитку, діагностику та корекцію / М. І. Загородній, І. А. Свінціцький // Практикуючий лікар. - 2013. - № 2. - C. 12-27.
ISSN 2706-6282(print) ISSN 2706-6290(online) 


\section{REFERENCES}

1. Hnatjuk MS, Bodnarchuk IV, Tatarchuk LV. [Features of structural reconstruction of arteries of the tongue at desquamative glossitis]. Visn nauk dosl. 2019;2: 85-9. DOI: 10.11603/2415-8798.2019.2.10022. Ukrainian.

2. Makarov MA., Avdyeev SH,Chuchalin AG. [The role of endothelial dysfunction and arterial rigidity in pathogenesis of chronic obstructive pulmonary disease]. Ter. Arkh. 2012;84(3): 74-80. Russian.

3. Hnatjuk MS, Bodnarchuk IV, Tatarchuk LV, Hasiuk PA. Age-related features of tongue remodeling in the experimental animals. Biomedical and biosocial anthropology. 2018;33: 36-40. Ukrainian. DOI: 10.31393/ bba33-2018-06

4. Kashinath Nayak A, Anoop T, Sacohidanand S. A clinicoetiological study of uretritis in man attending sexually transmitted disease clinic at a tertiary hospital. Indian journal of sexually transmitted disease and AIDS. 2017;38(2): 13641. DOI: 10.4103/ijstd.IJSTD_98_15

5. HoralskyiLP, KhomychVT, KononskyiOI. Fundamentals of histological technique and morphofunctional methods of research in normal and pathology. [Основи гістологічної техніки та морфоорункціональних методів дослідження в нормі та при патології : навч. посіб.] Zhytomyr: Polissia; 2011. Ukrainian.

6. Shormanov SV, Kulikov SV. [Histological and ultrastructural changers of liver at experimental stenosis of pulmonary trunk at insuficience]. Morfologiya. 2010;3: 4650. Russian.
7. Avtandilov GG. Basis of quantitative pathological anatomy. [Основы количественной патологической анатомии] Moscow: Meditsyna; 2002. Russian.

8. Wogenvoort CA, Wogenvoort N. Smooth muscle content of pulmonary arterial media in pulmonary venous hypertension compared with forms of pulmonary hypertension. Pulmonary venous hypertension. 1982;81(5): 681-585. DOI: 10.1378/chest.81.5.581

9. Grjibovski AM, Ivanov SV, Gorbatova MA. Analysis of quantitative data in two independent samples using Statistica and SPSS software: parametric and nonparametric tests. Science and Healthcare. 2016;2: 5-28. Russian. DOI: 10.34689/SH.2016.18.3.001

10. Resnikov OG. General ethical principles of experiments on animals. Endocrinology. 2003;8: 142-5. Russian.

11. Sarkisov DS. Structural basis adaptation and compensation damage function. [Структурные основы адаптации и компенсации нарушенных фрункций] Moscow: Meditsyna; 1998. Russian.

12. Ashcheulova TV. Apoptosis: signaling pathways and significance in cardiometabolic pathology. [Апоптоз: сигнальні шляхи та значення при кардіометаболічній патологіï] Kharkov, 2016. Ukrainian.

13. Zahorodnyi MI, Svintsitskyi IA. Endothelial dysfunction in hypertension: current views on the causes and pathogenetic mechanisms, diagnosis and therapeutic strategies. Prakt likar. 2013;2: 12-27. Ukrainian. 